J. Dairy Sci. 92:5139-5146

doi:10.3168/jds.2009-2224

(c) American Dairy Science Association, 2009.

\title{
Respiratory infections in Norwegian dairy calves
}

\author{
S. M. Gulliksen, ${ }^{*} \dagger^{1}$ E. Jor, $\ddagger$ K. I. Lie,${ }^{*}$ T. Løken, ${ }^{*}$ J. Åkerstedt, $\ddagger$ and O. Østerås ${ }^{*}$ \\ ${ }^{*}$ Norwegian School of Veterinary Science, PO Box 8146 Dep. NO-0033 Oslo, Norway \\ †TINE Norwegian Dairies, PO Box 58, NO-1431 Ås, Norway \\ ¥National Veterinary Institute, PO Box 750, NO-0106 Oslo, Norway
}

\section{ABSTRACT}

The aims of this study were to estimate the seroprevalence of respiratory agents in Norwegian dairy calves and to identify risk factors for respiratory disease. The participating 135 herds were randomly selected from those in The Norwegian Dairy Herd Recording System with at least 15 cow years. Each herd was followed for 1 yr. Blood samples from calves of $>150 \mathrm{~d}$ of age (n $=1,348$ ) were analyzed for antibodies against parainfluenza virus 3 , bovine coronavirus $(\mathrm{BCoV})$, bovine respiratory syncytial virus (BRSV), and Mycoplasma bovis. Calves reported to have been on pasture ( $\mathrm{n}=$ 139) were tested for antibodies against Dictyocaulus viviparus. Seroprevalences for parainfluenza virus 3, $\mathrm{BCoV}, \mathrm{BRSV}$, and D. viviparus at the calf level were $50.2,39.3,31.2$, and $4.3 \%$, respectively. No calves were antibody positive for $M$. bovis. Calves in herds with $\mathrm{BCoV}$-seropositive calves had an increased risk of respiratory disease compared with herds in which $\mathrm{BCoV}$ antibodies were not detected [hazard ratio $(\mathrm{HR})=3.9$ ], as had calves in herds in which the majority $(>54 \%)$ of the sampled calves were seropositive for BRSV (HR = 2.7). Other factors found to increase the risk of respiratory disease in calves were shared housing with cows during the first week of life compared with separate housing $(\mathrm{HR}=16.7)$, a larger herd size $(>50$ cow years $)$ compared with smaller herds $(\mathrm{HR}=8.2)$, more than an 8 -wk age difference between calves housed together in the same group pen compared with having pen mates of a more similar age $(\mathrm{HR}=3.9)$, previous recordings of diarrhea compared with no recorded diarrhea $(\mathrm{HR}=$ 3.9 ), and leaving calves with dams for $>24 \mathrm{~h}$ after birth compared with earlier separation $(\mathrm{HR}=3.5)$.

Key words: calf, respiratory disease, virus, risk factor

Received March 18, 2009.

Accepted June 23, 2009.

${ }^{1}$ Corresponding author: stine.gulliksen@veths.no

\section{INTRODUCTION}

The frequency and severity of bovine respiratory infections have increased globally, and respiratory disease is currently regarded as the principal health problem and the most economically important disease in calves (Svensson et al., 2003, 2006; Autio et al., 2007). The severity of respiratory disease seems to be influenced by immune status and the general condition of the animal, housing conditions, climate, management, and the presence and spreading of infectious agents.

Respiratory viruses, which are effectively spread by aerosol and direct contact between animals and herds, usually act in combination with other infectious agents, in particular bacteria, in the development of respiratory disease. Bovine respiratory syncytial virus (BRSV), parainfluenza virus 3 (PIV3), bovine coronavirus (BCoV), bovine viral diarrhea virus (BVD), and bovine herpes virus 1 , have been found to be the most important viruses associated with respiratory disease in calves and young stock (Autio et al., 2007). In a study of Norwegian dairy calves, Hyllseth et al. (1987) found that the overall seroprevalence was highest for PIV3, whereas antibodies against BRSV were less common. Norway has been declared free from BVD and infectious bovine rhinotracheitis, which is caused by bovine herpes virus 1 (Kampen et al., 2007a; 2007b). The major bacterial pathogens involved in respiratory disease, such as Mannheimia hemolytica, Pasteurella multocida, Arcanobacterium pyogenes, and Histophilus somni, may all be present as commensals in clinically healthy cattle, but secondary infections with one or more of these worsen the clinical outcome. Bovine mycoplasmas have been reported to be of increasing importance as a primary cause of calf pneumonia (Kusiluka et al., 2000), and are often isolated from pneumonic lungs in combination with other pathogens (Booker et al., 2008).

Dictyocaulus viviparus, which is one of the most important pathogenic nematodes in cattle, causes endemic disease in cattle kept on permanent pastures (Ploeger, 2002). Höglund et al. (2004) found animals infected with $D$. viviparus in both dairy and beef herds 
throughout Sweden. No studies on the prevalence and distribution of this parasite in Norwegian cattle have been carried out in recent decades.

The incidence of respiratory disease has been found to peak in calves at between 5 and 7 wk of age (Virtala et al., 1996). Respiratory diseases are often detected during autumn and winter (Svensson et al., 2006), and are frequently associated with poorly ventilated housing conditions (Callan and Garry, 2002) and drafts (Lundborg et al., 2005). The aims of the current study were to estimate the seroprevalence of BRSV, PIV3, BCoV, Mycoplasma bovis, and D. viviparus in Norwegian dairy calves and to identify risk factors for respiratory disease.

\section{MATERIALS AND METHODS}

\section{Study Herds}

The study was designed as a longitudinal, crosssectional survey. A multistage sampling procedure (Gulliksen et al., 2008) was used for random selection of herds registered in The Norwegian Dairy Herd Recording System (NDHRS) with at least 15 cow years (days from first calving to culling within $1 \mathrm{yr} / 365$ ) in 30 veterinary districts throughout Norway. Altogether, 193 dairy herds were invited to participate in the study, of which $135(69.9 \%)$ agreed. These herds were divided geographically into regions 1,2 , and 3 , respectively: eastern Norway $(\mathrm{n}=62)$, western Norway $(\mathrm{n}=23)$, and central and northern Norway $(\mathrm{n}=50)$. Each herd participated for 1 yr. For logistical reasons, herds in region 1 were enrolled during autumn 2004, herds in region 2 during spring 2005, and herds in region 3 during autumn 2005. The overall study period lasted from September 1, 2004, to January 31, 2007.

\section{Housing and Management}

The herd owners were sent a questionnaire comprising 55 questions on animal housing, management, and feeding routines (Table 1). Altogether, 125 of the 135 $(92.5 \%)$ participating farmers completed and returned the questionnaire.

\section{Health Registrations}

Health data were obtained from the NDHRS. Herds registered in this system report diseases, treatments, and preventive treatment for each animal on a regular basis (Østerås et al., 2007). Each cow has an individual "health card" that follows the animal from birth until culling or slaughter. Calves for meat production have a common health card in the herd.
Each herd received 12 additional health cards, one for each month, which were to be returned regardless of whether there was any information to register. In cases of disease for which a veterinarian was not consulted, the farmer was asked to record the event, based on definitions provided by the project. Respiratory disease was defined as coughing or sneezing accompanied by heavy breathing or nasal discharge for at least $2 \mathrm{~d}$.

\section{Sampling}

During the 2-yr period of fieldwork, a total of 64 local veterinarians were each responsible for between 1 and 14 herds, which they visited twice at approximately 6-mo intervals. On both visits, 6 calves of $>150 \mathrm{~d}$ of age were randomly selected for sampling. A blood sample was collected from a jugular vein from each calf and sent overnight to the National Veterinary Institute, Oslo, in a Styrofoam box with a cooling unit. Information on whether the calves had been on pasture was stated on the requisition form enclosed with the sample. Serum was stored at $-20^{\circ} \mathrm{C}$ until analysis.

\section{Laboratory Analyses}

Blood samples $(\mathrm{n}=1,348)$ were examined with ELISA kits for the presence of antibodies against PIV3, BCV, and BRSV (Svanovir, Svanova Biotech AB, Uppsala, Sweden), as well as M. bovis (BIO K 162 from Bio-X Diagnostics Sprl, Jemelle, Belgium) using the protocols provided by the manufacturers. Samples with positive or doubtful results for $M$. bovis were retested with a confirmatory ELISA (kindly supplied by Roger D. Ayling of the Mycoplasma Group, Veterinary Laboratories Agency, Weybridge, New Haw, Surrey, UK). Animals with a history of pasture $(\mathrm{n}=139)$ were tested by ELISA for antibodies against D. viviparus (Ceditest Lungworm Strip Kit, Cedi Diagnostics B.V., Lelystad, the Netherlands).

\section{Statistical Analyses}

Calves born in the 135 herds within the project period were included in the study $(\mathrm{n}=5,621)$. For descriptive statistics and statistical analyses, relevant NDHRS data were extracted and transferred, together with data recorded by the project, to SAS version 9.1 software (SAS Institute Inc., Cary, NC). Three separate Cox proportional hazard models (Cox, 1972) were fitted by using the PROC PHREG statement, with respiratory disease $(0 / 1)$ as the dependent variable based on recordings in the NDHRS.

In the first model, hierarchical dummy variables were created for the percentage of antibody-positive calves 
Table 1. Variables on housing and management extracted from a questionnaire from 125 dairy herds in a survey on calf health in Norway between 2004 and $2007^{1}$

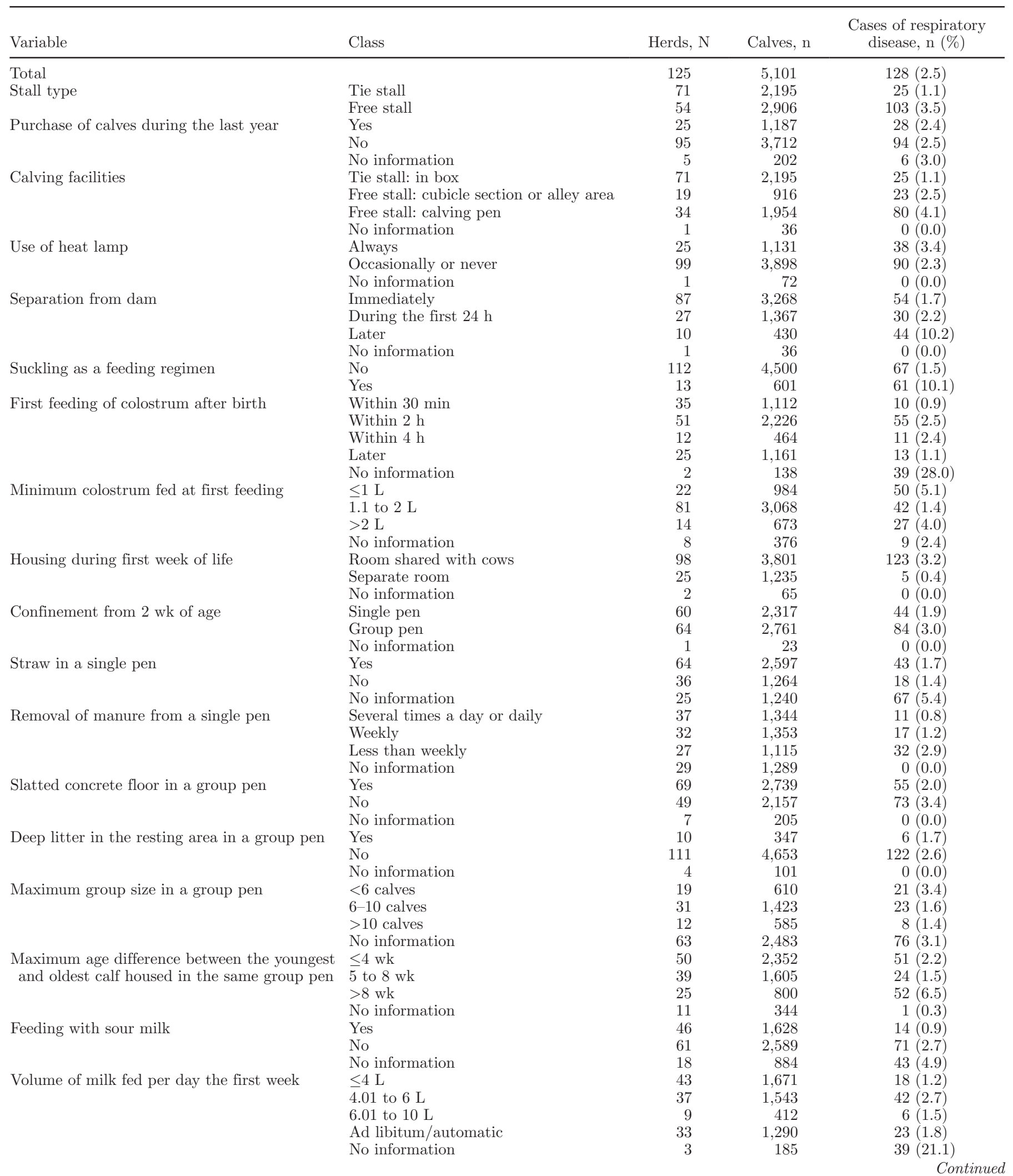


Table 1 (Continued). Variables on housing and management extracted from a questionnaire from 125 dairy herds in a survey on calf health in Norway between 2004 and $2007^{1}$

\begin{tabular}{|c|c|c|c|c|}
\hline Variable & Class & Herds, N & Calves, $\mathrm{n}$ & $\begin{array}{c}\text { Cases of respiratory } \\
\text { disease, } \mathrm{n}(\%)\end{array}$ \\
\hline \multirow[t]{4}{*}{ Volume of milk fed per day the second week } & $\leq 4 \mathrm{~L}$ & 39 & 1,691 & $31(1.8)$ \\
\hline & 4.01 to $6 \mathrm{~L}$ & 27 & 1,087 & $30(2.8)$ \\
\hline & Ad libitum/automatic & 46 & 1,663 & $21(1.3)$ \\
\hline & No information & 3 & 185 & $39(21.1)$ \\
\hline \multirow[t]{3}{*}{ Volume of milk fed per day the third week } & $\leq 4 \mathrm{~L}$ & 31 & 1,358 & $26(1.9)$ \\
\hline & Ad libitum/automatic & 60 & 2,210 & $30(1.4)$ \\
\hline & No information & 3 & 185 & $39(21.1)$ \\
\hline \multirow[t]{5}{*}{ Volume of milk fed per day the fourth week } & $\leq 4 \mathrm{~L}$ & 27 & 1,106 & $26(2.4)$ \\
\hline & $\overline{4} .01$ to $6 \mathrm{~L}$ & 17 & 653 & $7(1.1)$ \\
\hline & 6.01 to $10 \mathrm{~L}$ & 9 & 438 & $10(2.2)$ \\
\hline & Ad libitum/automatic & 69 & 2,719 & $46(1.7)$ \\
\hline & No information & 3 & 185 & $39(21.1)$ \\
\hline
\end{tabular}

${ }^{1}$ Only calves born and raised in the same herd are included.

in a herd. To obtain roughly equal numbers of animals in each category, the 10th, 25th, 50th, 75th, and 90th percentiles of the proportion of antibody-positive calves among those sampled per herd were used. For BCoV, the percentiles on a herd level corresponded to $>10$, $>33,>72$, and $>90 \%$ of the sampled calves being seropositive. The equivalent percentiles for BRSV were $>0$, $>30,>54$, and $>70 \%$, and for PIV3 were $>30,>58$, $>75$, and $>90 \%$, respectively. The infectious agents were first tested individually and then combined. In addition, dichotomous variables for herds with (1) or without (0) seropositive calves were created and tested separately for the 3 viruses.

In the second model, the influence of housing and management (Table 1) on the occurrence of diarrhea was studied, and herds for which the questionnaire had not been returned were excluded $(\mathrm{n}=10)$, leaving a total of 5,101 calves in the study population. A season variable was created for each calf based on its month of birth. Spring was defined as March through May, summer was defined as June through August, autumn was defined as September through November, and winter was defined as December through February. Hierarchical dummy variables were created for herd size divided into $>20,>50$, and $>70$ cow years. Hierarchical dummy variables were also created for parity of the dam divided into $>1,>2$, and $>3$ parities. Yearly milk yield in 1,000 $\mathrm{kg} /$ cow was included as a continuous variable.

In the third model, the significant variables from the first and second model were combined. Variables on commitment to calf health recordings were tested in the final model to adjust for differences in reported incidence of respiratory disease between herds caused by a lack of recordings (Gulliksen et al., 2009).

The positive stable frailty models in the SAS Macro (Shu and Klein, 1999, 2005) were included in all models. The significance of the frailty effect was assessed by the likelihood ratio test of independence $\left[\mathrm{H}_{0}\right.$ : theta $\left.(\theta)=1\right]$. The frailty effect equals the strength of association between 2 individuals within the same herd, as measured by Kendall's $\tau(1-\theta)$, and was considered significant at $P<0.05$. The end of the observation period in a calf was defined as $180 \mathrm{~d}$ of age if there was no event of respiratory disease. Data were censored when the animal left the herd because of sale or slaughter. Only the first case of respiratory disease from birth until $180 \mathrm{~d}$ of age was considered an event. The significance of the different variables was initially evaluated by univariate analysis. If the $P$-value was less than 0.1 , the variable was included in a final multivariable model. Nonsignificant variables were removed one by one by backward stepwise elimination, with the inclusion criterion of $P$

Table 2. Prevalence of antibodies against parainfluenza virus 3 (PIV3), bovine respiratory syncytial virus (BRSV), and bovine coronavirus (BCoV) in 1,348 calves aged 5 to 12 mo in 135 Norwegian dairy herds participating in a survey on calf health between 2004 and $2007^{1}$

\begin{tabular}{lcc}
\hline Agent & Seropositive calves, $\%$ & Positive herds, n (\%) \\
\hline PIV3 & $677(50.2)$ & $121(89.6)$ \\
BRSV & $420(31.2)$ & $96(71.1)$ \\
BCoV & $530(39.3)$ & $109(80.7)$ \\
\hline
\end{tabular}

${ }^{1}$ Herds having at least 1 antibody-positive calf were defined as positive. 
Table 3. Hazard ratio (HR) estimates for respiratory infection or not (0/1) using the Cox regression model accounting for cluster effects on herd level in 5,101 calves in 125 Norwegian dairy herds ${ }^{1}$

\begin{tabular}{|c|c|c|c|c|c|c|c|}
\hline Fixed effect & $\begin{array}{l}\text { Class, } \\
\text { mean (SD) }\end{array}$ & $\begin{array}{l}\text { Herds, } \\
\quad \mathrm{N}\end{array}$ & $\begin{array}{l}\text { Calves, } \\
\mathrm{n}\end{array}$ & $\begin{array}{l}\text { Estimate, } \\
\beta\end{array}$ & $\mathrm{SE}$ & $\begin{array}{c}\text { HR ( } 95 \% \\
\text { confidence interval) }\end{array}$ & $P$-value \\
\hline Herd size, cow years & $>50$ & 21 & 1,653 & 2.10 & 0.36 & $8.2(4.1-16.4)$ & $<0.001$ \\
\hline \multirow{2}{*}{ Separation from dam after calving } & $\leq 24 \mathrm{~h}$ & 114 & 4,635 & - & - & 1.0 & - \\
\hline & $\bar{N}_{o}$ information & 1 & 36 & - & - & - & - \\
\hline Sharing room with the cows during the first week of life & Yes & 98 & 3,801 & 2.81 & 0.88 & $16.7(3.0-92.8)$ & $<0.01$ \\
\hline \multirow{3}{*}{$\begin{array}{l}\text { Maximum age difference in weeks between the youngest } \\
\text { and oldest calf housed in the same group pen }\end{array}$} & $>8$ & 25 & 800 & 1.35 & 0.38 & $3.9(1.8-8.2)$ & $<0.001$ \\
\hline & $\leq 8$ & 89 & 3,957 & - & - & 1.0 & - \\
\hline & $\overline{\text { No information }}$ & 11 & 344 & - & - & - & NS \\
\hline \multirow[t]{3}{*}{ Feeding with sour milk } & No & 61 & 2,589 & 1.25 & 0.39 & $3.5(1.6-7.5)$ & $<0.01$ \\
\hline & Yes & 46 & 1,628 & - & - & 1.0 & - \\
\hline & No information & 18 & 884 & - & - & - & NS \\
\hline Previously recorded with diarrhea & Yes & & 201 & 1.37 & 0.27 & $3.9(2.3-6.7)$ & $<0.001$ \\
\hline \multirow{2}{*}{$\begin{array}{l}\text { Percentage of bovine respiratory syncytial } \\
\text { virus-seropositive calves } \\
\text { Milk yield, increase of } 1,000 \mathrm{~kg} \text { (continuous) } \\
\text { Theta, } 1 \text { - Kendall's tau }\end{array}$} & $7.0(0.88)$ & 125 & 5,101 & 0.39 & 0.19 & 1.5 & $<0.05$ \\
\hline & Herds & 125 & & 0.83 & 0.08 & & $<0.05$ \\
\hline
\end{tabular}

${ }^{1}$ The cluster effect within herd was assessed by the frailty effect (Kendall's tau).

$<0.05$. Possible interactions between significant fixed effects were tested.

\section{RESULTS}

\section{Respiratory Disease}

Respiratory disease was recorded at least once during the project period in 128 of the 5,101 (2.5\%) calves in the study herds. The distribution within each environmental risk factor is presented in Table 1.

\section{Seroprevalences}

The seroprevalences of PIV3, BCoV, and BRSV at the calf and herd level are presented in Table 2. Four calves tested positive for $M$. bovis with the Bio-X Diagnostics ELISA kit, but this result was not corroborated by the confirmatory test. A total of 6 of 139 (4.3\%) calves from 4 of $47(8.5 \%)$ herds were seropositive for D. viviparus.

\section{Risk Factors for Respiratory Infection}

Calves in herds with BCoV-seropositive calves had an increased risk of respiratory disease compared with herds in which calves with $\mathrm{BCoV}$ antibodies were not detected [hazard ratio $(\mathbf{H R})=3.9,95 \%$ confidence interval (CI): 1.0 to 15.5], as had calves in herds in which the majority $(>54 \%)$ of the sampled calves were seropositive for BRSV (HR $=2.7,95 \%$ CI: 1.3 to 5.8 ; Table 3$)$. Calves in herds with a high prevalence of PIV3 antibody-positive calves $(>58 \%)$ had an increased risk of respiratory disease ( $\mathrm{HR}=2.4,95 \%$ CI: 1.6 to 3.5), but this effect became nonsignificant when accounting for cluster effects. Parainfluenza virus 3 was not found to influence the risk of respiratory disease when variables on housing and management were included.

Other factors found to increase the risk of respiratory disease in calves were shared housing with cows during the first week of life compared with separate housing $(\mathrm{HR}=16.7)$, larger herds $(>50$ cow years $)$ compared with smaller herds $(\mathrm{HR}=8.2)$, more than an 8 -wk age difference between calves housed together in the same group pen compared with having pen mates of a more similar age $(\mathrm{HR}=3.9)$, a previous record of diarrhea compared with no recorded diarrhea $(\mathrm{HR}=3.9)$, and leaving calves with dams for $>24 \mathrm{~h}$ after birth compared with earlier separation $(\mathrm{HR}=3.5)$ (Table 3$)$.

Variables on time of the first colostrum feeding (Table 3) were highly correlated with herd size. No herds with $>50$ cow years reported feeding the first colostrum within 30 min after birth. Calves in herds in which the first colostrum was fed later than $30 \mathrm{~min}$ after birth had an increased risk of respiratory disease $(\mathrm{HR}=2.6$, 95\% CI: 1.3 to 5.2). Calves in herds in which the first colostrum was fed later than $4 \mathrm{~h}$ after birth, or herds in which information on colostrum feeding was missing, had a further increased risk $(\mathrm{HR}=2.0,95 \% \mathrm{CI}: 1.3$ to 3.2 ). 


\section{DISCUSSION}

\section{Respiratory Disease}

In this study, the $2.5 \%$ incidence of respiratory disease in calves was somewhat lower than has been reported in other countries (Gardner et al., 1990; Svensson et al., 2006), but by adjusting for missing records, an estimated "true" incidence of $4.1 \%$ of such disease was found in Norwegian dairy calves (Gulliksen et al., 2009). Variables on commitment to calf health recordings did not influence the risk of respiratory disease and were not considered confounders. This contrasts with the study of Lundborg et al. (2005), who found that on farms with poor record keeping, the risk of respiratory disease was increased.

\section{Seroprevalence}

To avoid interference from maternal antibodies, only samples from calves $>150 \mathrm{~d}$ were analyzed (Uttenthal et al., 2000). The present study shows that important respiratory pathogens are common in the Norwegian dairy cattle population, as in other cattle-producing countries (Härtel et al., 2004; Hägglund et al., 2006). Bovine respiratory syncytial virus, PIV3, and $\mathrm{BCoV}$ seem to be ubiquitous, because more than $70 \%$ of the herds were positive (Table 2). Antibodies against $M$. bovis were not found, and respiratory disease caused by this agent has apparently not been reported in Norway. A recent Finnish study also reported similar results for $M$. bovis (Autio et al., 2007). These results are in contrast to the situation reported in other countries, where $M$. bovis is considered an important cause of respiratory infections in cattle (Radaelli et al., 2008). The present results and the fact that Norway is recognized as free from important infectious diseases such as BVD and infectious bovine rhinotracheitis (Kampen et al., $2007 a, b)$ indicate that a restrictive import policy is probably beneficial because it limits the introduction of new infectious agents. Routine screening at high-risk settings, such as bull-testing facilities, may be an option for detecting the introduction of infectious respiratory diseases, and molecular characterization of isolated viruses from such a setting may be a useful tool for monitoring those strains that are actively circulating in the cattle population.

The incidence of $D$. viviparus was lower than that reported from Sweden (Hägglund et al., 2006). Cattle from regions with mild summers and heavy rainfall are usually most exposed to lungworm infections. Geographical differences in the incidence of $D$. viviparus may be due to climatic variations, but our material was insufficient to assess this possibility. A specific study to investigate these aspects of lungworm infections in more detail could provide useful results.

\section{Risk Factors for Respiratory Disease}

Our results showed that infections with BRSV, PIV3, and $\mathrm{BCoV}$ were common and were likely to cause respiratory disease in dairy calves throughout the country. Similar results have been obtained in other studies (Ganaba et al., 1995). When the viruses were included individually in separate models, all were apparently associated with an increased risk of respiratory disease. However, because the hierarchical dummy variables for percentage of antibody-positive calves in a herd were highly correlated, especially for $\mathrm{BCoV}$ and PIV3, it was difficult to determine the importance of each separate virus. Additionally, environmental and management factors within each herd seemed to influence the development and severity of disease during infections.

Bovine coronavirus causes not only respiratory distress in calves and adult cows (Decaro et al., 2008), but also diarrhea in calves (Snodgrass et al., 1986) as well as in adult cattle (winter dysentery; Saif et al., 1991). It is still unclear whether respiratory and enteric $\mathrm{BCoV}$ strains have distinct biological, antigenic, and genetic characteristics, although there seem to be some differences between these strains (Hasoksuz et al., 2002).

The dynamics of BRSV within herds has been widely discussed (Uttenthal et al., 2000; Hägglund et al., 2006). A high prevalence of calves seropositive for BRSV throughout the year may indicate that the infection is maintained within the herd. Bovine respiratory syncytial virus may survive within herds through persistently infected cattle, and a steady state of low-level reinfection might maintain a reservoir of infectious virus (Van der Poel et al., 1993).

Our results are consistent with those from a study by Norström et al. (2000), who found that the risk of respiratory infections was greater in large herds $(>50$ cows) than in smaller herds. The number of animals susceptible to infections in large herds is higher than in small herds, which could contribute to maintaining infections circling within a herd over extended periods. The degree of human traffic and spreading of infectious agents between herds would also be greater in larger herds; therefore, the importance of establishing biosafety routines should be considered higher in larger herds than in smaller ones. Calves in larger herds tend to be more densely housed, resulting in closer animalto-animal contact, which could promote the spread of infections. Svensson and Liberg (2006) found that calves housed in group pens of more than 12 calves had an increased risk of respiratory disease. Nonsupervised calvings have also been associated with an increased 
risk of respiratory disease (Svensson et al., 2003), and as herd size increases, the daily inspection of individual animals might be reduced.

Because the time of the first colostrum feeding was highly correlated with herd size, a satisfactory colostrum-feeding regimen appears to be more difficult to establish in large herds. Variables on colostrum feeding were not included in the final model because inclusion of herd size gave a significantly better model fit. Nevertheless, these results emphasize the need for adequate colostrum feeding to reduce the possibility of respiratory disease.

Five of the $10(50.0 \%)$ herds in which the calves were left with their dam for more than $24 \mathrm{~h}$ reported that suckling was the only routine for colostrum supply. Both factors were found to have a significant effect on the occurrence of respiratory infection when cluster effects at the herd level were not included. Although the presence of the dam and suckling might increase the amount of IgG absorbed (Quigley et al., 1995), calves left to suckle their dams have often been found to have insufficient IgG intake (Trotz-Williams et al., 2008) and the risk of disease in these calves is higher (Svensson et al., 2003). Additional colostrum, fed manually by bottle, seems beneficial if the calf and dam are left together.

As has been reported in other studies (Svensson et al., 2006), calves diagnosed with diarrhea during their first months of life had a significantly higher risk of respiratory disease than calves without previous diarrhea. This might be due to common predisposing factors, such as inadequate passive transfer of IgG; poor climatic conditions, as well as an immunosuppressive effect of the infectious agents involved; and nutritional and electrolyte imbalance because of the diarrhea.

The majority of Norwegian dairy calves are housed together with the milking herd, and cows may act as reservoir for infectious diseases in calves. Depending on animal density, the load of infectious agents in a stall housing both calves and cows is likely to be considerably higher than in a stall housing only calves, thereby increasing the risk of infections. However, young cattle should be regarded as the primary reservoir and as important contributors for most infectious calf pathogens (E. Jor, National Veterinary Institute, Oslo, personal communication). Svensson et al. (2003) found an increased risk of respiratory disease in calves of 1 to 12 wk of age housed in group pens of 6 to 30 animals compared with calves housed in smaller groups. Minimizing the age difference between calves housed in the same group pen is favorable because older calves are often the source of infection for younger calves (Maddox-Hyttel et al., 2006).

High milk yield was associated with an increased risk of respiratory disease. This could be related to the lower colostral IgG content found in high-yielding cows (Gulliksen et al., 2008), probably because of a dilution effect.

In conclusion, PIV3, BCoV, and BRSV are widespread in Norwegian dairy cattle, but environmental factors seem to have a considerable influence on the development and severity of disease during infections. Finding associations between the prevalence of seropositive calves and risk factors for respiratory disease could be a first step in determining the role of respiratory pathogens, but further studies are needed to establish their clinical importance.

\section{ACKNOWLEDGMENTS}

The authors thank all the participating farmers, veterinarians, and laboratory personnel. We also thank Roger D. Ayling of the Mycoplasma Group, Veterinary Laboratories Agency (Weybridge, New Haw, Surrey, UK). The study was funded by TINE Norwegian Dairies BA (Ås, Norway), Animalia (Løren, Norway), and the Norwegian Research Council (Oslo, Norway). Access to production and health data was given by The Norwegian Dairy Herd Recording System and The Norwegian Cattle Health Services in agreement number 8/2002.

\section{REFERENCES}

Autio, T., T. Pohjanvirta, R. Holopainen, U. Rikula, J. Pentikäinen, A. Huovilainen, H. Rusanen, T. Soveri, L. Sihvonen, and S. Pelkonen. 2007. Etiology of respiratory disease in non-vaccinated, nonmedicated calves in rearing herds. Vet. Microbiol. 119:256-265.

Booker, C. W., S. M. Abutarbush, P. S. Morley, G. K. Jim, T. J. Pittman, O. C. Schunicht, T. Perrett, B. K. Wildman, R. K. Fenton, P. T. Guichon, and E. D. Janzen. 2008. Microbiological and histopathological findings in cases of fatal bovine respiratory disease of feedlot cattle in Western Canada. Can. Vet. J. 49:473481.

Callan, R. J., and F. B. Garry. 2002. Biosecurity and bovine respiratory disease. Vet. Clin. North Am. Food Anim. Pract. 18:57-77.

Cox, D. R. 1972. Regression models and life-tables (with discussion). J. R. Stat. Soc., B 34:187-220.

Decaro, N., M. Campolo, C. Desario, F. Cirone, M. D'Abramo, E. Lorusso, G. Greco, V. Mari, M. L. Colaianni, G. Elia, V. Martella, and C. Buonavoglia. 2008. Respiratory disease associated with bovine coronavirus infection in cattle herds in Southern Italy. J. Vet. Diagn. Invest. 20:28-32.

Ganaba, R., D. Bélanger, S. Dea, and M. Bigras-Poulin. 1995. A seroepidemiological study of the importance in cow-calf pairs of respiratory and enteric viruses in beef operations from northwestern Quebec. Can. J. Vet. Res. 59:26-33.

Gardner, I. A., D. W. Hird, W. W. Utterback, C. Danaye-Elmi, B. R. Heron, K. H. Christiansen, and W. M. Sischo. 1990. Mortality, morbidity, case-fatality, and culling rates for California dairy cattle as evaluated by the National Animal Health Monitoring System, 1986-87. Prev. Vet. Med. 8:157-170.

Gulliksen, S. M., K. I. Lie, and O. Østerås. 2009. Calf health monitoring in Norwegian dairy herds. J. Dairy Sci. 92:1660-1669.

Gulliksen, S. M., K. I. Lie, L. Sølverød, and O. Østerås. 2008. Risk factors associated with colostrum quality in Norwegian dairy cows. J. Dairy Sci. 91:704-712.

Hägglund, S., C. Svensson, U. Emanuelson, J. F. Valarcher, and S. Alenius. 2006. Dynamics of virus infections involved in the bovine 
respiratory disease complex in Swedish dairy herds. Vet. J. 172:320-328.

Härtel, H., S. Nikunen, E. Neuvonen, R. Tanskanen, S. L. Kivelä, R. Aho, T. Soveri, and H. Saloniemi. 2004. Viral and bacterial pathogens in bovine respiratory disease in Finland. Acta Vet. Scand. 45:193-200.

Hasoksuz, M., S. Sreevatsan, K. O. Cho, A. E. Hoet, and L. J. Saif. 2002. Molecular analysis of the S1 subunit of the spike glycoprotein of respiratory and enteric bovine coronavirus isolates. Virus Res. 84:101-109.

Höglund, J., S. Viring, and M. Tornqvist. 2004. Seroprevalence of Dictyocaulus viviparus in first grazing season calves in Sweden. Vet. Parasitol. 125:343-352.

Hyllseth, B., H. J. Larsen, and K. Norheim. 1987. Calf virus infections in Norway, a serosurvey. Page 321 in Proc. VII Int. Congr. Virology, Edmonton, Canada. The National Research Council, Ottawa, Ontario, Canada.

Kampen, A. H., J. Åkerstedt, S. Gudmundsson, P. Hopp, G. Grøneng, and O. Nyberg. 2007a. The surveillance and control programme for bovine virus diarrhoea (BVD) in Norway. Pages $65-71$ in Surveillance and Control Programmes for Terrestrial and Aquatic Animals in Norway-Annual Report 2006. E. Brun, ed. The National Veterinary Institute, Oslo, Norway.

Kampen, A. H., J. Tharaldsen, and G. Grøneng. 2007b. The surveillance and control programme for infectious bovine rhinotracheitis (IBR) and infectious pustular vulvovaginitis (IPV) in Norway. Pages 49-54 in Surveillance and Control Programmes for Terrestrial and Aquatic Animals in Norway-Annual Report 2006. E. Brun, ed. The National Veterinary Institute, Oslo, Norway.

Kusiluka, L. J., B. Ojeniyi, and N. F. Friis. 2000. Increasing prevalence of Mycoplasma bovis in Danish cattle. Acta Vet. Scand. 41:139146.

Lundborg, G. K., E. C. Svensson, and P. A. Oltenacu. 2005. Herd-level risk factors for infectious diseases in Swedish dairy calves aged 0-90 days. Prev. Vet. Med. 68:123-143.

Maddox-Hyttel, C., R. B. Langkjaer, H. L. Enemark, and H. Vigre. 2006. Cryptosporidium and Giardia in different age groups of Danish cattle and pigs-Occurrence and management associated risk factors. Vet. Parasitol. 141:48-59.

Norström, M., E. Skjerve, and J. Jarp. 2000. Risk factors for epidemic respiratory disease in Norwegian cattle herds. Prev. Vet. Med. 44:87-96.

Østerås, O., H. Solbu, A. O. Refsdal, T. Roalkvam, O. Filseth, and A. Minsaas. 2007. Results and evaluation of thirty years of health recordings in the Norwegian dairy cattle population. J. Dairy Sci. 90:4483-4497.

Ploeger, H. W. 2002. Dictyocaulus viviparus: Re-emerging or never been away? Trends Parasitol. 18:329-332.

Quigley, J. D. III, K. R. Martin, D. A. Bemis, L. N. Potgieter, C. R. Reinemeyer, B. W. Rohrbach, H. H. Dowlen, and K. C.
Lamar. 1995. Effects of housing and colostrum feeding on serum immunoglobulins, growth, and fecal scores of Jersey calves. J. Dairy Sci. 78:893-901.

Radaelli, E., M. Luini, G. R. Loria, R. A. Nicholas, and E. Scanziani. 2008. Bacteriological, serological, pathological and immunohistochemical studies of Mycoplasma bovis respiratory infection in veal calves and adult cattle at slaughter. Res. Vet. Sci. 85:282-290.

Saif, L. J., K. V. Brock, D. R. Redman, and E. M. Kohler. 1991 Winter dysentery in dairy herds: Electron microscopic and serological evidence for an association with coronavirus infection. Vet. Rec. 128:447-449.

Shu, Y., and J. P. Klein. 1999. A SAS macro for the positive frailty model. Pages 47-52 in Proc. Am. Stat. Assoc., Statistical Computing Section. Am. Stat. Assoc., Alexandria, VA.

Shu, Y., and J. P. Klein. 2005. A SAS macro for the positive stable frailty model. http://www.biostat.mcw.edu/software/SoftMenu. html Accessed June 12, 2008.

Snodgrass, D. R., H. R. Terzolo, D. Sherwood, I. Campbell, J. D. Menzies, and B. A. Synge. 1986. Aetiology of diarrhoea in young calves. Vet. Rec. 119:31-34.

Svensson, C., J. Hultgren, and P. A. Oltenacu. 2006. Morbidity in 3-7-month-old dairy calves in south-western Sweden, and risk factors for diarrhoea and respiratory disease. Prev. Vet. Med. 74:162-179.

Svensson, C., and P. Liberg. 2006. The effect of group size on health and growth rate of Swedish dairy calves housed in pens with automatic milk-feeders. Prev. Vet. Med. 73:43-53.

Svensson, C., K. Lundborg, U. Emanuelson, and S. O. Olsson. 2003 Morbidity in Swedish dairy calves from birth to 90 days of age and individual calf-level risk factors for infectious diseases. Prev. Vet. Med. 58:179-197.

Trotz-Williams, L. A., K. E. Leslie, and A. S. Peregrine. 2008. Passive immunity in Ontario dairy calves and investigation of its association with calf management practices. J. Dairy Sci. 91:3840-3849.

Uttenthal, A., L. E. Larsen, J. S. Philipsen, K. Tjørnehøj, B. Viuff, K. H. Nielsen, and T. K. Nielsen. 2000. Antibody dynamics in BRSVinfected Danish dairy herds as determined by isotype-specific immunoglobulins. Vet. Microbiol. 76:329-341.

Van der Poel, W. H., J. A. Kramps, W. G. Middel, J. T. Van Oirschot and A. Brand. 1993. Dynamics of bovine respiratory syncytial virus infections: A longitudinal epidemiological study in dairy herds. Arch. Virol. 133:309-321.

Virtala, A. M., G. D. Mechor, Y. T. Gröhn, H. N. Erb, and E. J. Dubovi. 1996. Epidemiologic and pathologic characteristics of respiratory tract disease in dairy heifers during the first three months of life. J. Am. Vet. Med. Assoc. 208:2035-2042. 